Bangladesh J. Bot. 41(1): 119-121, 2012 (June)

- Short communication

\title{
LIMNOLOGICAL NOTES ON RAMSAGAR, DINAJPUR, BANGLADESH
}

\author{
Moniruzzaman KhondKeR*, Md Almujaddade Alfasane, \\ Mo Ataul Gani and Mo Shafiqul Islam
}

\author{
Department of Botany, University of Dhaka, Dhaka-1000, Bangladesh
}

Key words: Ramsagar, Phytoplankton, Water quality

\begin{abstract}
Ramsagar, an artificial lake of Dinajpur district has been investigated limnologically. Mean alkalinity, DO, pH, TDS and conductivity of the lake were $0.50 \mathrm{meq} / \mathrm{l}, 7.99 \mathrm{mg} / \mathrm{l}, 6.73,10.66 \mathrm{mg} / \mathrm{l}$ and $73.66 \mu \mathrm{S} / \mathrm{cm}$, respectively. The concentration of soluble reactive phosphorus and silicate was very low. Mean value of the former parameter was $3.16 \mu \mathrm{g} / \mathrm{l}$ and the latter was $0.77 \mathrm{mg} / \mathrm{l}$. Nitrate-nitrogen concentration was $<0.1 \mathrm{mg} / \mathrm{l}$. Phytoplankton biomass as chl $a$ was $5.92 \mu \mathrm{g} / \mathrm{l}$ and that of phaeopigment $3.65 \mu \mathrm{g} / \mathrm{l}$. Phytoplankton flora of the lake was found to be dominated by desmids. The dominant species were Staurastrum coarctatum var. subcurtum $\left(59.35 \times 10^{4} \mathrm{ind} / \mathrm{l}\right)$; S. subgracillimum var. tortum $\left(44.83 \times 10^{4} \mathrm{ind} / \mathrm{l}\right)$ and $S$. leptacanthum $\left(29.06 \times 10^{4} \mathrm{ind} / \mathrm{l}\right)$. Among the blue-green algae, Anabaena utermöhlii was dominant. Chlorococcales was represented by seven species. The total density of phytoplankton was $163.53 \times 10^{4} \mathrm{ind} / \mathrm{l}$. Considering the overall limnological characteristics, the lake could be characterized as acidic and nutrient poor.
\end{abstract}

Besides three natural lakes of Bangladesh (Khan et al. 1994, Rashid 1991, Khondker et al. 2010), some artificial or man-made lakes are also present. The word 'Sagar' (= sea) is commonly attached to their names to represent large sized water body and is a legendary of the Hindu Zamindars of the then Bengal under British India. Dharma Sagar of Comilla district, Joy Sagar of Sirajganj district, Ramsagar of Dinajpur district and Nilsagar of Nilphamari district are some of the known water bodies of this category. Their basins are quite old and are usually dug out manually to meet the demand of drinking and domestic water supply in the area and considered as a ritual well being to the belief of Hindu Zamindars. The basin of Ramsagar was dug out by the King Ramnath of Dinajpur between 1750 and 1755 AD.

Nahar and Khondker (2009) and Nahar et al. (2010) studied the epipelic diatom and their relationships with the limnological parameters of Jaysagar. Aziz and Tanbir (2003) studied a few phytoplankton of Ramsagar. But there is no information regarding the water quality of Ramsagar. So, the present attempt has been made to study the water quality and the status of phytoplankton community of Ramsagar.

Ramsagar is $1.03 \mathrm{~km}$ long and $0.36 \mathrm{~km}$ wide and is located on a 60 ha elevated land which is about $8 \mathrm{~km}$ south of Dinajpur city. The area of the water body is 31.53 ha having an average depth of $9.14 \mathrm{~m}$. The catchment is occupied by secondary forests and managed by the forest department of Bangladesh and the lake is taken care by the fisheries department. The area has been considered as tourist spot and nearly 150000 tourists visit the area every year.

Water sample from $10 \mathrm{~cm}$ depth was collected by dipping a two litre capacity polystyrene bottle from the southern part of the lake on 24 April, 2011. The bottle was covered by dark papers and carried to the laboratory for further analyses. Triplicate Pyrex BOD bottle (125 ml cap.) was filled in situ and fixed by adding each of $1 \mathrm{ml}$ of manganous sulphate and alkaline iodide solution for DO analysis. Another one litre sample of the lake was fixed by adding Lugol's solution for the qualitative and quantitative analyses of phytoplankton. All the samples were transported to the

*Author for correspondence: <mkhondker@yahoo.com> 
Hydrobiology and Limnology laboratory, Department of Botany, University of Dhaka and the chemical analysis was completed within next 24 hours. Methodologies followed have been described in Khondker et al. (2010).

Table 1. Some water quality parameters of Ramsagar.

\begin{tabular}{lcccccccccc}
\hline $\begin{array}{l}\text { Sample } \\
(\mathrm{n})\end{array}$ & $\begin{array}{c}\text { Alkalinity } \\
(\mathrm{meq} / \mathrm{l})\end{array}$ & $\begin{array}{c}\mathrm{DO} \\
(\mathrm{mg} / \mathrm{l})\end{array}$ & $\mathrm{pH}$ & $\begin{array}{c}\mathrm{TDS} \\
(\mathrm{mg} / \mathrm{l})\end{array}$ & $\begin{array}{c}\text { Conduc- } \\
\text { tivity } \\
(\mu \mathrm{S} / \mathrm{cm})\end{array}$ & $\begin{array}{c}\mathrm{SRP} \\
(\mu \mathrm{g} / \mathrm{l})\end{array}$ & $\begin{array}{c}\mathrm{SRS} \\
(\mathrm{mg} / \mathrm{l})\end{array}$ & $\begin{array}{c}\mathrm{NO}_{3}-\mathrm{N} \\
(\mathrm{mg} / \mathrm{l})\end{array}$ & $\begin{array}{c}\mathrm{Chl} a \\
(\mu \mathrm{g} / \mathrm{l})\end{array}$ & $\begin{array}{c}\text { Phaeo- } \\
\text { pigment } \\
(\mu \mathrm{l} / \mathrm{l})\end{array}$ \\
\hline 1 & 0.50 & 8.54 & 6.73 & 11 & 75 & 2.97 & 1.06 & 0.098 & 5.92 & 3.65 \\
2 & 0.60 & 8.13 & 6.71 & 10 & 72 & 3.84 & 0.56 & 0.095 & 5.75 & 3.15 \\
3 & 0.40 & 7.32 & 6.75 & 11 & 74 & 2.68 & 0.71 & 0.085 & 6.09 & 4.15 \\
Mean & 0.50 & 7.99 & 6.73 & 10.66 & 73.66 & 3.16 & 0.77 & 0.093 & 5.92 & 3.65 \\
SD & 0.10 & 0.62 & 0.02 & 0.57 & 1.52 & 0.60 & 0.25 & 0.007 & 0.17 & 0.50 \\
\hline
\end{tabular}

Table 2. Abundance of phytoplankton of Ramsagar.

\begin{tabular}{llc}
\hline Division & Species & $\begin{array}{c}\text { Density } \\
\left(\times 10^{4} \text { ind/l) }\right.\end{array}$ \\
\hline Cyanophyta & Anabaena variabilis Kütz. ex Born. et Flah. & 2.96 \\
& A. utermöhlii Geitler & 3.20 \\
Chlorophyta & Ankistrodesmus falcatus var. stipitatus (Chodat) Lemmermann & 0.99 \\
& Chlorogonium elongatum (Dang.) France & 0.25 \\
& Crucigenia tetrapedia (Kirchner) W. West and G.S. West & 0.49 \\
& Scenedesmus arcuatus Lemmermann & 1.48 \\
& Schroederia setigera (Schröd.) Lemmermann & 2.96 \\
& Sphaerozosma aubertianum West & 11.33 \\
& Staurastrum coarctatum Bréb. var. subcurtum Nordst. & 59.35 \\
& Staurastrum leptacanthum Nordst. & 29.06 \\
& Staurastrum subgracillimum var. tortum Scott \& Grönblad & 44.83 \\
& Staurastrum validus (W. \& W.) Thomasson & 0.25 \\
& Tetraedron trigonum (Nägeli) Hansgirg & 0.49 \\
& Westella botryoides de Wilderman & 0.74 \\
Euglenophyta & Trachelomonas volvocina Ehrenberg & 1.97 \\
Chrysophyta & Navicula menisculus Schum & 0.25 \\
Cryptophyta & Ceratium hirundinella (O. F. Müller) Dujardin & 1.48 \\
\hline Total & Mallomonas corymbosa Asmund et Hilliard & 1.72 \\
\hline & & 163.53 \\
\hline
\end{tabular}

During the present investigation the limnological parameters thus obtained are presented in Table 1. It showed that the mean alkalinity, DO, $\mathrm{pH}$, TDS and conductivity of the lake were 0.50 meq/l, $7.99 \mathrm{mg} / \mathrm{l}, 6.73,10.66 \mathrm{mg} / \mathrm{l}$ and $73.66 \mu \mathrm{S} / \mathrm{cm}$, respectively. The water quality data of Ramsagar have been compared with those of Joysagar (Nahar et al. 2010) and it has been observed that the mean alkalinity of water is almost same in both the water bodies. But the mean values of conductivity, SRP and SRS are lower in Ramsagar, which are 1.47, 25.27 and 14.84-fold higher, respectively in Joysagar. Mean nitrate concentration in Joysagar was found to be 97.70 $\mu \mathrm{g} / \mathrm{l}$. On the other hand, this was below $0.1 \mathrm{mg} / \mathrm{l}$ in Ramsagar. 
Phytoplankton biomass as chl $a$ was $5.92 \mu \mathrm{g} / \mathrm{l}$ and that of phaeopigment was $3.65 \mu \mathrm{g} / \mathrm{l}$. In a mesotrophic pond, values of these variables ranged from $7.91-19.83$ and $1.54-8.17 \mu \mathrm{g} / \mathrm{l}$, respectively (Khondker and Kabir 1995). Phytoplankton flora of the lake was found to be dominated by desmids (Table 2). The dominant species were Staurastrum coarctatum var. subcurtum (59.35 $\times 10^{4}$ ind/l), S. subgracillimum var. tortum $\left(44.83 \times 10^{4}\right.$ ind/l) and S. leptacanthum $\left(29.06 \times 10^{4} \mathrm{ind} / \mathrm{l}\right)$. Among Cyanophyta, Anabaena utermöhlii and A. variabilis were dominant. Chlorococcales was represented by 7 genera but their individual population density was low (Table 2). The total density of phytoplankton was $163.53 \times 10^{4}$ ind $/$.

Since, the limnological information of the present study is based on the analysis of a single sample, it only reflects the water quality at a given time. However, by comparing the data of previously studied water bodies and dominance of desmid flora the present water body may be suggested to be acidic in nature and also nutrient poor.

Among macrophytes Nymphoides cristatum (Roxb.) O. Kuntze and Aponogeton appendiculatus Bruggen were found to be dominant during the present investigation.

\section{References}

Aziz A and M Tanbir 2003. Algal flora of some northern districts of Bangladesh. Bangladesh J. Plant Taxon. 10(1): 63-78.

Khan MS, E Haq, S Huq, AA Rahman, SMA Rashid and H Ahmed 1994. (Eds). Wetlands of Bangladesh. BCAS, Dhaka. 91 pp.

Khondker M and MA Kabir. 1995. Phytoplankton primary production in a mesotrophic pond in sub-tropical climate. Hydrobiologia 304:39-47.

Khondker M, MA Alfasane, MS Islam, MAH Bhuiyan and A Goni 2010. Limnology of Lake Bogakine, Bandarban. Bangladesh J. Bot. 39(2): 153-159.

Nahar K and M Khondker 2009. Addition to the list of freshwater diatoms (Bacillariophyceae) of Bangladesh. I. Family: Coscinodiscaceae, Fragilariaceae and Eunotiaceae. J. Taxon. Biodiv. 3: 9-12.

Nahar K, M Khondker and M Sultana 2010. Seasonal succession and diversity of benthic diatom of two wetland ecosystems of Bangladesh. Bangladesh J. Bot. 39(1): 29-36.

Rashid HEr 1991. Geography of Bangladesh. Univ. Press Ltd. Dhaka. 529 pp.

(Manuscript received on 4 March, 2012; revised on 10 April, 2012) 